\title{
Sticky coffee hull silage on the feeding of growing and finishing pigs
}

\author{
Paulo Levi de Oliveira Carvalho ${ }^{1}$ Ivan Moreira ${ }^{2}$, Antonio Claudio Furlan², Diovani Paiano ${ }^{3}$, \\ Liliane Maria Piano ${ }^{1}$, Lina Maria Peñuela Sierra ${ }^{1}$
}

\begin{abstract}
1 Pós-Graduação em Zootecnia da Universidade Estadual de Maringá. Av. Colombo, 5790, 87020-900, Maringá - Paraná.
${ }^{2}$ Departamento de Zootecnia - Universidade Estadual de Maringá, Av. Colombo, 5790, 87020-900, Maringá - Paraná.

3 Departamento de Zootecnia - Universidade do Estado de Santa Catarina, R. Benjamim Constant, 84, 89801-070, Chapecó- Santa Catarina.
\end{abstract}

ABSTRACT - Two experiments were carried out with the objective of evaluating the performance and carcass traits of growing and finishing pigs fed rations with sticky coffee hull silage. In experiment 1 , the coffee hulls were ground through a 4-mm screen and ensiled with 30\% water and enzymatic-bacterial inoculant and evaluated in digestibility trial with 15 crossbred pigs distributed in a completely randomised design. Overall, the ensiling process did not improve the digestibility of the sticky coffee hulls. In experiment 2, it was used 60 pigs (32.52 to $59.58 \mathrm{~kg}$ ) in the growing phase and 55 pigs (61.70 to $90.27 \mathrm{~kg})$ in the finishing phase, distributed in a completely randomised design with five diets $(0,4,8,12$ and $16 \%$ of sticky coffee hull silage) and six replicates. In the growing and finishing phase, inclusion of levels of sticky coffee hull silage did not affect feed intake, weight gain, and plasma urea nitrogen. However, in the finishing phase, feed conversion improved as the levels of sticky coffee hull silage increased. Responses by backfat thickness and marbling were quadratic, whereas empty stomach weight increased linearly when sticky coffee hull silage was included in the diet. Sticky coffee hull silage has good nutritional value and if used in levels up to $16 \%$ of the diet, it does not impair performance of pigs in the growing and finishing phases and it results in leaner carcasses. However, the economic feasibility of its use depends on the price relationship of this by-product with the other feedstuffs.

Key Words: alternative feeds, by-product, carcass traits, digestibility, performance

\section{Casca de café melosa ensilada na alimentação de suínos na fase de crescimento e terminação}

\begin{abstract}
RESUMO - Foram conduzidos dois experimentos com o objetivo de avaliar o desempenho e as características de carcaça de suínos na fase de crescimento e terminação alimentados com rações contendo casca de café melosa ensilada. No experimento 1, a casca de café foi moída em peneira com crivos de $4 \mathrm{~mm}$ e ensilada com 30\% de água e inoculante enzimobacteriano e avaliada em ensaio de digestibilidade com 15 suínos mestiços, distribuídos em delineamento inteiramente casualizado. De forma geral, o processo de ensilagem não melhorou a digestibilidade da casca de café melosa. No experimento 2, foram utilizados 60 suínos $(32,52$ a $59,58 \mathrm{~kg})$ na fase de crescimento e 55 suínos $(61,70$ a 90,27 kg) na fase de terminação, distribuídos em delineamento inteiramente casualizado, com cinco dietas $(0,4,8,12$ e $16 \%$ de casca de café melosa ensilada) e seis repetições. Nas fases de crescimento e terminação, não houve efeito dos níveis de casca de café melosa ensilada sobre o consumo de ração, o ganho de peso e o nitrogênio da uréia plasmática. Entretanto, na fase de terminação, a conversão alimentar melhorou com o aumento dos níveis de casca de café melosa ensilada. A espessura de toucinho e o marmoreio responderam de forma quadrática, enquanto o peso do estômago vazio aumentou de forma linear com a inclusão de casca de café melosa ensilada na dieta. A casca de café melosa ensilada tem bom valor nutricional e, se utilizada em níveis correspondentes a até $16 \%$ da dieta, não prejudica o desempenho de suínos nas fases de crescimento e terminação e resulta em carcaças mais magras, entretanto a viabilidade econômica de sua utilização depende da relação de preços entre esse subproduto e os demais ingredientes.
\end{abstract}

Palavras-chave: alimentos alternativos, característica de carcaça, desempenho, digestibilidade, subproduto

\section{Introduction}

Feeding has a greater impact on the costs of pig production than any other component. Accordingly, there is a great market interest in finding alternative feedstuffs that allow costs to be reduced while achieving good productive and reproductive performance. Factors such as commercial availability, quality and price can have an impact on the choice of such alternative feedstuffs.

In Brazil, some agricultural productions result in a high volume of by-products, such as coffee hulls, which may be used in alternative animal feeds. Brazilian coffee production 
is estimated at 33,740 million bags of processed coffee per year, according to CONAB (2008). As coffee hull production corresponds to approximately $40 \%$ of total coffee production (Poveda Parra et al., 2008), an estimated 810 million tonnes of this by-product are produced every year.

The use of this by-product to feed pigs depends fundamentally on its chemical composition, digestibility values and nutrient availability (Ferreira et al., 1997; Moreira et al., 2009). Sticky coffee hull (SCH) residue is more nutritious than the other coffee components because it has high levels of crude protein and low levels of fiber (Vilela et al., 2001). As SCH does not contain parchment, a highly fibrous component, it is notably more effectively utilised by pigs (Oliveira et al., 2001).

Research on pigs suggests that sticky coffee hull levels of up to $5 \%$ can be included in feed during the growing phase (Oliveira et al., 2001 Poveda Parra et al., 2008) and up to $9.5 \%$ during the finishing phase (Poveda Parra et al., 2008) without impairing performance and even improving the quality of the carcass.

Ensiling may improve the utilisation and conservation of this agro-industrial waste, making nutrients more available, reducing anti-nutritional factors, such as caffeine, tannins and polyphenols, and reducing the environmental impact resulting from the high volume of this waste.

Accordingly, this study was carried out aiming to evaluate the nutritional value of sticky coffee hull silage (SCHS) on growing-finishing pig feeding and its effects on performance, carcass traits and the economic feasibility.

\section{Material and Methods}

Two experiments were carried out to evaluate sticky coffee hull silage on growing-finishing pigs feeding.

The sticky coffee hulls were obtained from the COCAMAR agro-industry and ground in a hammer-knife mill with a 4-mm mesh, as recommended by Poveda Parra et al. (2008), who demonstrated that sticky coffee hulls ground to a larger grain size $(4 \mathrm{~mm})$ are better digested than 2.5-mm hulls.

The sticky coffee hull silage was obtained by adding water to increase the moisture level to about 30\%. Enzymaticbacterial inoculant was also added to the water to improve the fermentation process. The coffee hulls were ensiled in 70-L plastic drums with hermetically sealed lids at a density of $930 \mathrm{~kg} \mathrm{SHCS} / \mathrm{m}^{3}$. The silage was used after a minimum fermentation period of 30 days.

Two experiments were conducted: a test to evaluate digestibility (experiment 1 ) and a study of performance (experiment 2). In experiment 1 , a total of 15 castrated male crossbred pigs with a mean initial weight of $43.06 \pm 4.12 \mathrm{~kg}$ from a commercial line were used.

The animals were maintained in individual metabolism cages similar to those described by Pekas (1968), in a building with a partially controlled environment. The ambient temperature varied from $18^{\circ} \mathrm{C}$ to $25.1^{\circ} \mathrm{C}$.

Two experimental diets were tested by replacing $25 \%$ on dry matter basis of the control diet with sticky coffee hulls and sticky coffee hull silage. The control diet consisted of corn (72.90\%), soybean meal (24.45\%), salt (0.57\%), limestone (0.64\%), dicalcium phosphate (0.87\%) and vitamin and mineral supplement $(0.57 \%)$ and was formulated to meet the requirements NRC (1998). The feed containing sticky coffee hull silage was prepared daily.

The experimental period was 17 days (twelve days for adaptation and five days for total collection of feces and urine). A completely randomized experimental design was used with two diets and five replicates. The experimental unit consisted of one pig.

During the collection period, the quantity of diet provided was calculated from the metabolic weight $\left(\mathrm{kg}^{0.75}\right)$ of each pig. Average intake was recorded during the adaptation period. The feeding was provided at 8 a.m. and 4 p.m. daily. The two meals were $55 \%$ of the total in the morning and $45 \%$ in the afternoon (a proportion obtained from the morning and afternoon feed intake during the adaptation period). The feeds were moistened with approximately $20 \%$ water to avoid waste, reduce dustiness and improve the acceptability of the diet. After each meal, water was provided at the feeder in the proportion of $3 \mathrm{~mL}$ of water/g of diet to prevent excessive water consumption.

With the objective of defining the start and the end of the period of total collection of feces, $3 \%$ iron oxide $\left(\mathrm{Fe}_{3} \mathrm{O}_{2}\right)$ was used as a fecal marker. The feces were collected once a day, kept in plastic bags and stored in a freezer $\left(-18^{\circ} \mathrm{C}\right)$. Subsequently, the material was thawed, homogenised and dried (approximately $350 \mathrm{~g}$ ) in a forced draught oven at $55^{\circ} \mathrm{C}$ for $72 \mathrm{~h}$ and ground in a knife mill (1-mm screen). The urine was collected in plastic buckets, containing $20 \mathrm{~mL}$ of $\mathrm{HCl}$ 1:1 to prevent bacteria proliferation and possible volatilisation losses.

The chemical composition of the diets and the feces were evaluated by the Laboratório de Nutrição Animal at Universidade Estadual de Maringá, in accordance with the methodologies described by Silva \& Queiroz (2002). Granulometry analysis was conducted in accordance with the methodology proposed by Zanotto \& Bellaver (1996). Gross energy values were determined using an adiabatic 
calorimeter (Parr Instrument Co. AC720), following the procedures described by Silva \& Queiroz (2002).

Caffeine levels were determined by the Instituto de Tecnologia de Alimentos - ITAL, following the methodology described by Horwitz (2005), and the total tannin levels were determined by the Departamento de Farmácia da Universidade Estadual de Maringá. Aminogram analysis of the sticky coffee hulls was carried out by the Laboratório da Degussa using HPLC equipment.

The coefficients for dry matter digestibility, gross energy, organic matter, crude protein, neutral detergent fiber, acid detergent fiber, gross fiber and hemicellulose were calculated in accordance with the reports by Matterson et al. (1965).

To evaluate the differences between the digestibility coefficients for SCH and the SCHS, the coefficients were submitted to analysis of variance (F test, $\mathrm{P}>0.05$ ), using the SAEG statistics package (UFV, 1997), in accordance with the following statistical model: $\mathrm{Y}_{i j}=\mu+\mathrm{Ti}+\mathrm{e}_{i j}$, where: $\mathrm{Y}_{i j}=$ digestibility coefficient for treatment $\mathrm{i}$, with repetition $\mathrm{j} ; \mu=$ constant related to all observations; $\mathrm{T}_{i}=$ effect of the type of feed $\mathrm{i}$, in which $\mathrm{i}=1 ; 2$ (1= SCH and $2=\mathrm{ESCH})$; and $\mathrm{ij}=$ random error associated with each observation.

In experiment 2, a total of 60 crossbred pigs, 30 castrated males and 30 females from a commercial line were used, with an average initial weight of $32.52 \pm 3.21$ and final weight of $59.58 \pm 4.01 \mathrm{~kg}$ and, in the finishing phase, 55 pigs with an initial weight of $61.70 \pm 3.29 \mathrm{~kg}$ and final weight of $90.27 \pm 3.56 \mathrm{~kg}$.

The experiments related to the growing and finishing phases were carried out from October 2006 to January 2007. The mean minimal temperatures recorded in the experimental periods were, respectively, $19.6 \pm 2.4^{\circ} \mathrm{C}$ and $20.5 \pm 1.5^{\circ} \mathrm{C}$, and the mean maximal temperatures were, respectively, $30.6 \pm 2.9^{\circ} \mathrm{C}$ and $29.8 \pm 2.9^{\circ} \mathrm{C}$. The values for mean air relative humidity recorded in the experimental periods in the growing and finishing phases were, respectively, $78.5 \pm 13.6 \%$ and $84.2 \pm 11.0^{\circ} \mathrm{C}$ in the morning and, respectively, $51.7 \pm 12.7 \%$ and $65.7 \pm 15.9 \%$ in the afternoon.

The animals were kept in brick barns with cement fiber roofs. Each pen had a water drinking nipple and a semiautomatic feeder, providing free access to the feed and the water. The pens had shallow pools $(0.8 \times 2.0 \mathrm{~m}) \pm 10 \mathrm{~cm}$ deep $(0.8 \times 2.0 \mathrm{~m})$ and the water was renewed twice a week.

Five diets containing $0,4,8,12$ and $16 \%$ sticky coffee hull silage were used. The diets were based on corn and soybean meal (Table 1) and formulated to meet the NRC (1998) requirements for pigs in the growing phase (30 to $60 \mathrm{~kg}$ body weight) and finishing phase (60 to $90 \mathrm{~kg}$ body weight).
The chemical and energy composition of the sticky coffee hull silage (Table 2), obtained from the digestibility test, was used for formulating the diets. The values of crude protein, phosphorous and calcium were determined for the other feedstuffs, such as corn and soybean meal, considering the level of digestible energy, as given by Rostagno et al. (2005).

The pigs were allocated in a completely randomised design for five diets, in six replicates in the growing phase and five replicates in the finishing phase. The experimental unit consisted of a pen with two animals. However, in the finishing phase, there was only one animal per pen. At the end of the growing phase, the animals were randomly reallocated to the experimental units and treatments for the finishing phase. This ensured a balanced distribution for each finishing treatment, avoiding concentrating animals from a particular growing phase group.

The diets and animals were weighed at the start and end of the experiment to calculate daily feed intake, daily weight gain, and the feed:gain ratio for each experimental unit. At the end of the finishing phase, backfat thickness and loin depth at position $\mathrm{P}_{2}$ were measured using Sono-Grader equipment $\left(\right.$ Renco $\left.^{\circledR}\right)$.

Blood samples (Cai et al., 1994) for subsequent plasma urea nitrogen (PUN) analysis were collected at the beginning (baseline) and at the end (final plasma urea nitrogen) of the experimental period in the growing and finishing phases. Levels of plasma urea nitrogen measured using the method described by Marsh et al. (1965), and the baseline results obtained at the beginning of the experiment were used as co-variables in the statistical analysis of the final plasma urea nitrogen.

At the end of the finishing phase, 50 pigs (five males and five females from each group) were slaughtered. The carcasses were refrigerated (at 1 to $2^{\circ} \mathrm{C}$ ) for $24 \mathrm{~h}$ and submitted to quantitative analysis in accordance with the brazilian carcass grade methodology (ABCS, 1973). Samples of the longissimus dorsi in the region of the $8^{\text {th }}$ and $10^{\text {th }}$ vertebrae were extracted for qualitative analysis of the carcasses and used in subsequent measurement of intramuscular fat, that is, marbling and drip loss, as described by Bridi \& Silva (2006). The longissimus dorsi and fat areas were determined using a Tablet Running Spring software (Câmara et al., 1996).

To evaluate the economic feasibility of sticky coffee hull silage, market prices of raw materials were studied and the cost of feed per kilogram of weight gain was calculated, following Bellaver et al. (1985). The economic and cost efficiency indicators were also calculated, following the methodology proposed by Gomes et al. (1991). The prices 
Table 1 - Centesimal, energy and chemical composition of diets containing sticky coffee hull silage for growing and finishing pigs feeding

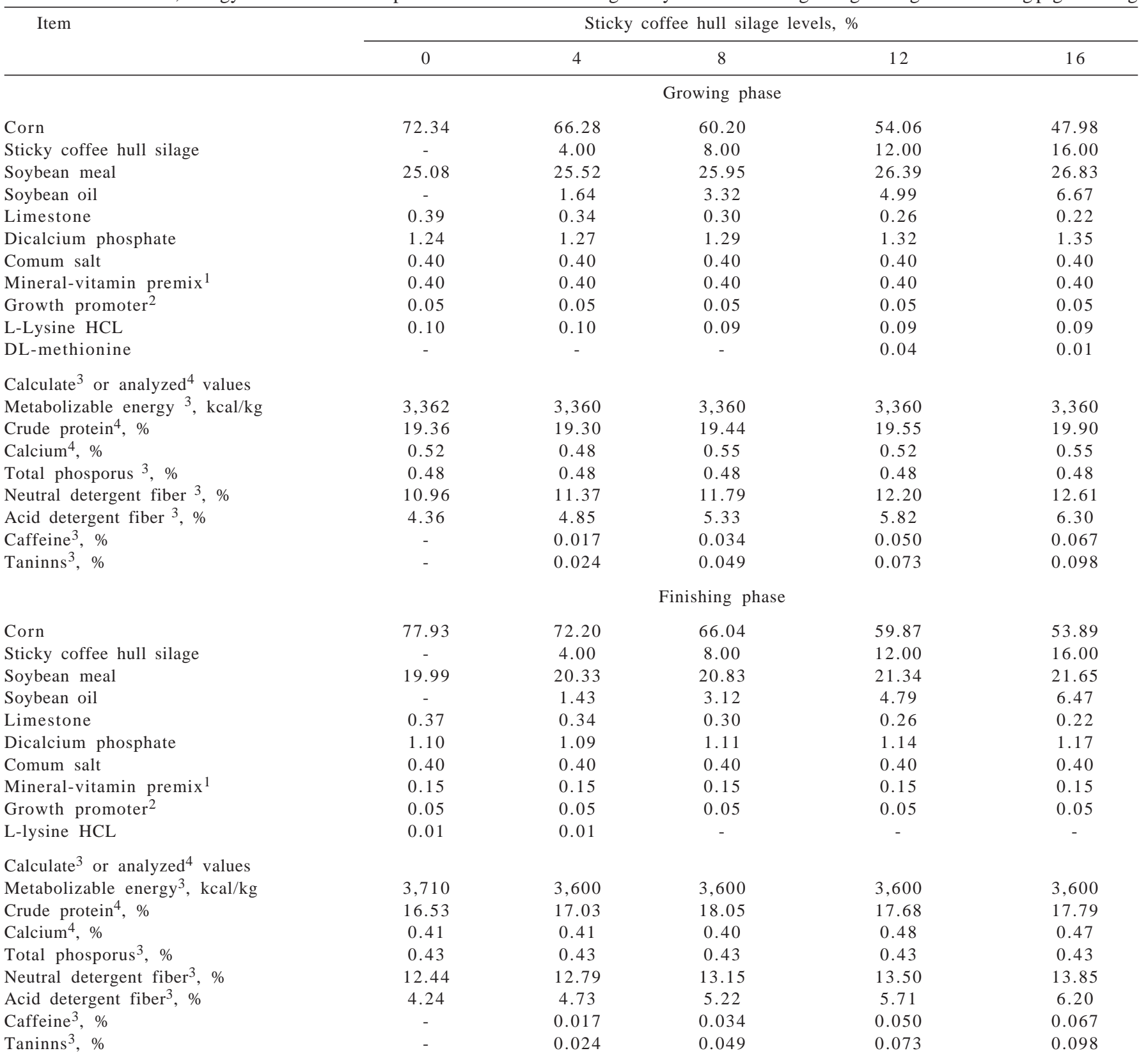

${ }^{1}$ Vitamin and mineral premix for growing and finishing pigs; ${ }^{2}$ Lincomicyn (30\%); ${ }^{3}$ Calculate based on Rostagno et al. (2005) and/or analyzed; ${ }^{4}$ Analysis obtained at the Laboratório de Nutrição Animal of the Universidade Estadual de Maringá.

of the raw materials used to calculate the costs of the experimental diets were: corn grain, $\mathrm{R} \$ 0.42 / \mathrm{kg}$; soybean meal, R\$ 0.70/kg; soybean oil, R\$3.20/kg; and sticky coffee hull silage, $\mathrm{R} \$ 0.33 / \mathrm{kg}$.

The results for the studied variables were submitted to analysis of variance is in accordance with the following statistical model: $Y_{i j}=\mu+N_{i}+e_{i j}$, in which $Y_{i j}=$ observed value for the studied variables relating to each individual $j$, receiving the level $i$ of the sticky coffee hull silage; $\mu=$ general constant; $\mathrm{N}_{\mathrm{i}}=$ levels of sticky coffee hull silage in the diets, in which $\mathrm{i}=0,4,8,12$ and $16 \%$; $\mathrm{e}_{\mathrm{ij}}$ = random error associated with each observation. The effect of gender was included in the model for PUN and carcass traits $\left(\mathrm{S}_{\mathrm{k}}=\right.$ effect of gender $\mathrm{k}(1$ = male, 2 = female $)$ ). In addition, the level effects were derived in orthogonal polynomials to determine the regression equations.

The quadratic model (derivation of the quadratic equation) was applied to variables showing a quadratic response $(\mathrm{P} \leq 0.05)$ to the levels of sticky coffee hull silage to define the best inclusion level of sticky coffee hull silage. The Dunnett test (Sampaio, 1998) was used to compare the control diet results (without sticky coffee hull silage) to each level of sticky coffee hull silage. The statistics software SAEG (UFV, 1997) was used for the statistical analysis. 


\section{Results and Discussion}

The ensiling process reduced (on the dry matter basis) the fiber fraction of the sticky coffee hulls by approximately $25 \%$ of the neutral detergent fiber and acid detergent fiber, $32 \%$ of the crude fiber, $27 \%$ of the cellulose, $23 \%$ of the hemicellulose and $13 \%$ of the lignin, which may explain the increase (24\%) in the level of non-fibrous carbohydrates in the sticky coffee hull silage (Table 2). Mitaru et al. (1984) stated that the ensiling process, which involves the addition of water and subsequent anaerobic incubation at $25^{\circ} \mathrm{C}$, removes up to $97 \%$ of the chemically detectable tannin. These changes may explain some of the alteration in the digestibility of the sticky coffee hull silage (Tables 3 and 4) and in the performance of the pigs (Table 5).

In general, ensiling did not improve $(\mathrm{P}>0.05)$ the digestibility of the sticky coffee hulls inasmuch as the digestibility of some of the components, such as dry matter, gross energy and organic matter, did not change $(\mathrm{P}>0.05)$ (Table 3 and 4). However, the digestibility coefficients of crude protein, neutral detergent fiber, acid detergent fiber and crude fiber decreased. These results do not support the initial hypothesis that ensiling might improve the nutritional value of the sticky coffee hulls. Similar results were obtained for soybean hulls by Quadros et al. (2007), who observed that ensiling did not affect the digestibility of dry matter, organic matter and gross energy of this by-product.

The addition of enzymatic-bacterial inoculant did not improve the utilisation of the fibrous fraction of the sticky coffee hulls as expected inasmuch as the digestibility of the fibrous components and crude protein was lower $(\mathrm{P}<0.05)$ than in the sticky coffee hulls (Tables 3 and 4$)$. The characteristics of the by-product, the changes that occured

Table 2 - Chemical, energetic and physical composition of sticky coffee hull and sticky coffee hull silage

\begin{tabular}{|c|c|c|c|c|}
\hline Item & \multicolumn{2}{|c|}{ Sticky coffee hull } & \multicolumn{2}{|c|}{ Sticky coffee hull silage } \\
\hline Dry matter, \% & 88.80 & 100 & 67.48 & 100 \\
\hline Crude protein, \% & 8.69 & 9.79 & 6.75 & 10.01 \\
\hline Lysine, \% & 0.19 & 0.21 & 0.14 & 0.21 \\
\hline Methionine + cystine, \% & 0.17 & 0.19 & 0.13 & 0.19 \\
\hline Ash, \% & 5.70 & 6.42 & 4.58 & 6.79 \\
\hline Organic matter \% & 82.70 & 93.40 & 62.84 & 93.14 \\
\hline Ether extract, \% & 0.59 & 0.66 & 1.04 & 1.89 \\
\hline Neutral detergent fiber, \% & 34.47 & 38.82 & 21.78 & 32.27 \\
\hline Acid detergent fiber, \% & 23.25 & 34.45 & 18.19 & 26.96 \\
\hline Crude fiber, \% & 20.06 & 22.59 & 10.50 & 15.56 \\
\hline Lignin, \% & 5.67 & 6.39 & 3.76 & 5.57 \\
\hline Caffeine, \% & 0.50 & 0.56 & 0.42 & 0.62 \\
\hline Taninn, \% & 1.06 & 1.19 & 0.61 & 0.90 \\
\hline $\mathrm{pH}$ & 4.51 & - & 4.32 & - \\
\hline Geometric mean diameter, $\mu \mathrm{m}$ & 1,784 & - & 2,062 & - \\
\hline
\end{tabular}

Table 3 - Apparent digestibility coefficients (DC), metabolization coefficient (MC) of nutrients of sticky coffee hull and sticky coffee hull silage used on growing-finishing pigs feeding ${ }^{1}$

\begin{tabular}{|c|c|c|c|}
\hline Coefficients, \% & Sticky coffee hull & Sticky coffee hull silage & $\mathrm{SD}^{2}$ \\
\hline DC of dry matter & $60.13 \mathrm{a}$ & $55.02 \mathrm{a}$ & \pm 4.86 \\
\hline DC of gross energy & $56.90 \mathrm{a}$ & $49.87 a$ & \pm 5.31 \\
\hline MC of gross energy & $54.43 a$ & $47.30 \mathrm{a}$ & \pm 8.74 \\
\hline DC of organic matter & $61.28 \mathrm{a}$ & $54.02 \mathrm{a}$ & \pm 5.51 \\
\hline DC of crude protein & $38.83 a$ & $15.00 \mathrm{~b}$ & \pm 13.01 \\
\hline DC of neutral detergent fiber & $54.77 \mathrm{a}$ & $36.66 \mathrm{~b}$ & \pm 10.43 \\
\hline DC of acid detergent fiber & $58.35 a$ & $39.01 b$ & \pm 10.45 \\
\hline DC of crude fiber & $55.39 a$ & $33.78 b$ & \pm 12.18 \\
\hline
\end{tabular}

${ }^{1} \mathrm{DC}$ values with different letters in the same row differ $(\mathrm{P}<0.05)$ by $\mathrm{F}$ test; ${ }^{2}$ Standard deviation. 
Table 4 - Digestible values of nutrients of sticky coffee hull and sticky coffee hull silage used on growing-finishing pigs feeding

\begin{tabular}{|c|c|c|c|c|}
\hline \multirow[t]{2}{*}{ Digestible nutrients } & \multicolumn{2}{|c|}{ Sticky coffee hull } & \multicolumn{2}{|c|}{ Sticky coffee hull silage } \\
\hline & As fed basis & Dry matter & As fed basis & Dry matter \\
\hline Dry matter (\%) & 53.40 & - & 37.13 & - \\
\hline Digestible energy (kcal/kg) & 2,143 & 2,413 & 1,431 & 2,120 \\
\hline Metabolizable energy (kcal/kg) & 2,050 & 2,308 & 1,357 & 2,011 \\
\hline Organic matter $(\%)$ & 50.82 & 57.23 & 46.15 & 50.31 \\
\hline Crude protein (\%) & 3.38 & 3.80 & 1.01 & 1.50 \\
\hline Neutral detergent fiber (\%) & 18.88 & 21.26 & 7.98 & 11.83 \\
\hline Acid detergent fiber (\%) & 17.85 & 20.10 & 7.10 & 10.52 \\
\hline Crude fiber (\%) & 11.11 & 12.51 & 3.55 & 5.26 \\
\hline
\end{tabular}

during fermentation, and the addition of the inoculant probably reduced the quality of the fibers (Rodrigues et al., 2005), reducing the digestibility of the nutrients in the fibrous fraction of the sticky coffee hull silage. A reduction of approximately $12 \%$ in the value of the digestible energy from the sticky coffee hull silage (in the dry matter) when compared to that of the non-ensiled hulls is possibly due to the reduction in fiber quality.

Fibrous feeds may increase the excretion of metabolic and microbial nitrogen in pigs, reduce the availability of nitrogen and other nutrients and increase the excretion of nitrogen and other bound nutrients or those physically shielded from enzymatic action (Stanogias \& Pearce, 1985a,b).

The digestibility results for sticky coffee hull silage are lower than those obtained by Ferreira et al. (1997), Santos et al. (2005) and Poveda Parra et al. (2008) for digestible energy (2,843, 2,799, and 2,498 kcal/kg respectively) and for the digestibility coefficient for crude protein $(45.68,53.80$, and $65.54 \%$ respectively). Similarly, the values found are lower than those reported by Ferreira et al. (1997), Oliveira et al. (2002) and Santos et al. (2005) for digestible dry matter (61.02, 65.65, and 65.5\% respectively) and metabolizable energy (2,694, 2,320, and 2,684 kcal/kg respectively).
In experiment 2 (Table 5), the performance of the animals and the concentrations of PUN in the growing phase were not influenced $(\mathrm{P}>0.05)$ by the levels of sticky coffee hull silage, probably because the diets were isoenergetic, as soybean oil had been added to correct the energy deficiency. In the same way, synthetic amino acids (lysine and methionine) were added (Table 1 ), which is reflected in the similar values for PUN ( $\mathrm{P}>0.05)$, showing that the protein quality of the diets was similar (Coma et al., 1995) for the different levels of sticky coffee hull silage.

The results for daily feed intake met the expected result, possibly because the diets with a higher percentage of sticky coffee hull silage showed the best palatability, in proportion to the soybean oil added to the diet and the reduction in the tannins in the sticky coffee hull silage (Table 2), which may have contributed to make the feeds more acceptable by the pigs. These results differ from those obtained by Oliveira et al. (2001), Oliveira et al. (2002) and Poveda Parra et al. (2008), who provided coffee hulls to pigs in the growing and finishing phases and found a reduction in fed intake and weight gain. According to these authors, the greater quantity of fiber in the feed and the presence of tannins and caffeine may produce a bitter taste that directly influences digestibility and palatability.

Table 5 - Performance and carcass traits ${ }^{1}$ of growing-finishing pigs fed on diets with sticky coffee hull silage

\begin{tabular}{|c|c|c|c|c|c|c|c|c|}
\hline \multirow[t]{2}{*}{ Item } & \multicolumn{5}{|c|}{ Sticky coffee hull silage levels, \% } & \multirow[t]{2}{*}{ Mean } & \multirow{2}{*}{$\begin{array}{c}\text { Standard } \\
\text { deviation }\end{array}$} & \multirow[t]{2}{*}{ Regression $^{2}$} \\
\hline & 0 & 4 & 8 & 12 & 16 & & & \\
\hline \multicolumn{9}{|c|}{ Growing } \\
\hline Daily feed intake (kg) & 1.919 & 1.834 & 1.831 & 1.742 & 1.703 & 1.806 & \pm 0.26 & $\mathrm{~L}: 0.13$ \\
\hline Daily weight gain (kg) & 0.823 & 0.744 & 0.775 & 0.764 & 0.738 & 0.769 & \pm 0.08 & $\mathrm{~L}: 0.14$ \\
\hline Feed:gain ratio & 2.340 & 2.456 & 2.361 & 2.274 & 2.312 & 2.349 & \pm 0.23 & 0.99 \\
\hline Plasma urea nitrogen (mg/dL) & 15.06 & 14.45 & 14.73 & 14.27 & 13.85 & 14.48 & \pm 2.57 & 0.99 \\
\hline \multicolumn{9}{|c|}{ Finishing } \\
\hline Daily feed intake (kg) & 2.466 & 2.479 & 2.352 & 2.403 & 2.266 & 2.393 & \pm 0.21 & $L: 0.06$ \\
\hline Daily weight gain (kg) & 0.811 & 0.808 & 0.778 & 0.831 & 0.803 & 0.806 & \pm 0.07 & 0.99 \\
\hline Feed:gain ratio & 3.050 & 3.071 & 3.033 & 2.903 & 2.836 & 2.979 & \pm 0.21 & $\mathrm{~L}: 0.03$ \\
\hline BT - P2 (mm) & 10.70 & 10.40 & 10.90 & 10.20 & 10.89 & 10.61 & \pm 2.09 & 0.99 \\
\hline Loin depth (mm) & 55.90 & 54.80 & 55.10 & 52.80 & 54.11 & 54.55 & \pm 5.41 & 0.99 \\
\hline Plasma urea nitrogen (mg/dL) & 15.19 & 14.28 & 15.06 & 14.92 & 14.78 & 14.85 & \pm 1.87 & 0.99 \\
\hline
\end{tabular}

${ }^{1} \mathrm{BT}-\mathrm{P} 2$ = Backfat thickness in position $2 ;{ }^{2}$ Levels of significance by F test in regression analysis: $\mathrm{L}=$ Linear effect; Feed to gain ratio $=3.1358-0.01490853 \mathrm{X}$. 
As expected, the results obtained in the finishing phase were similar to those in the growing phase (Table 5). In this phase, only the feed:gain ratio improved linearly as the level of sticky coffee hull silage increased. This response might have been influenced by the addition of soybean oil to the experimental diets in proportion to the increase in the level of added fibrous feed to overcome the energy deficiency resulting from the addition of sticky coffee hull silage, a result similar to that reported by Quadros et al. (2008) in a study of soybean hulls provided to pigs in the growing phase.

Except for backfat thickness and marbling score, none of the other carcass traits (Table 6) were influenced ( $\mathrm{P}>0.05$ ) by the addition of sticky coffee hull silage. The backfat thickness and marbling score varied quadratically $(\mathrm{P}<0.05)$ with the inclusion of sticky coffee hull silage, and the levels of 8.4 and $7.8 \%$ resulted in the least backfat and marbling score, respectively. This response can be explained by the fact that the sticky coffee hull silage is a low-energy fibrous food, which may have led to a small reduction in energy consumption and influenced the carcass traits, resulting in a lower amount of fat, without effecting daily weight gain, and even improving the feed:gain ratio (Table 5). According to Gomes et al. (2007), this reduction in body fat and increase in muscle mass improves the quality of the carcass, even though they are commonly associated with lower body weight gain, which did not occur in this experiment (Table 5).
The results obtained in this study are similar to those found by Oliveira et al. (2002), who evaluated sticky coffee hulls for pigs in the finishing phase and found a quadratic response in the percentage of fat and backfat thickness at $\mathrm{P}_{2}$ position. On the other hand, Pond et al. (1988) and Quadros et al. (2008) used fibrous foods (alfalfa hay and soybean hulls, respectively) and obtained a linear reduction in backfat thickness.

Empty stomach weight increased linearly $(\mathrm{P}<0.05)$ as sticky coffee hull silage increased, which suggests greater development of the stomach with the greater volume of feed intake when sticky coffee hull silage was included in the diet. Gomes et al. (2006) found the gastrointestinal tract to be heavier and the empty stomach weight to be greater in pigs fed diet containing $8 \%$ neutral detergent fiber. Results obtained by other authors (Pond et al., 1988; Pond \& Varel, 1989) confirm the effect of fiber on the weight of the digestive organs, such as the liver, kidneys, empty stomach, cecum and colon.

The results of the economic analysis (Table 7) showed a linear increase $(\mathrm{P}<0.05)$ in the cost of feed per kilogram of weight gain as the levels of sticky coffee hull silage increased in the diets of pigs in the growing and finishing phases.

In both phases, levels of 12 and 16\% of sticky coffee hull silage raised the cost of the feed (per kg of live weight gain) in comparison with the levels 0,4 , and $8 \%$. This

Table 6 - Carcass traits of pigs fed diets with sticky coffee hull silage

\begin{tabular}{|c|c|c|c|c|c|c|c|c|}
\hline \multirow[t]{2}{*}{ Item } & \multicolumn{5}{|c|}{ Sticky coffee hull silage levels, \% } & \multirow[t]{2}{*}{ Mean } & \multirow{2}{*}{$\begin{array}{c}\text { Standard } \\
\text { deviation }\end{array}$} & \multirow[t]{2}{*}{ Regression } \\
\hline & 0 & 4 & 8 & 12 & 16 & & & \\
\hline \multicolumn{9}{|l|}{ Carcass traits } \\
\hline Fasting losses $(\%)$ & 2.91 & 3.54 & 3.53 & 3.73 & 3.75 & 3.49 & \pm 1.036 & $\mathrm{~L}: 0.07$ \\
\hline Hot carcass weight $(\mathrm{kg})$ & 73.27 & 73.54 & 73.33 & 73.65 & 72.93 & 73.34 & \pm 3.950 & 0.99 \\
\hline Hot carcass yield $(\%)$ & 83.73 & 83.44 & 83.45 & 83.85 & 83.48 & 83.59 & \pm 1.165 & 0.99 \\
\hline Loss of yield (\%) & 3.73 & 3.52 & 3.53 & 3.80 & 3.50 & 3.62 & \pm 1.102 & 0.99 \\
\hline Ham yield (kg) & 32.49 & 32.22 & 32.74 & 32.35 & 30.84 & 32.15 & \pm 1.492 & Q:0.07 \\
\hline Ham weight (kg) & 11.45 & 11.41 & 11.57 & 11.39 & 10.86 & 11.35 & \pm 0.709 & $\mathrm{Q}: 0.12$ \\
\hline Backfat thickness (cm) & 2.70 & 2.31 & 2.45 & 2.27 & 2.63 & 2.47 & \pm 0.366 & Q:0.01 \\
\hline Carcass length $(\mathrm{cm})$ & 89.85 & 90.14 & 90.33 & 91.19 & 90.87 & 90.46 & \pm 2.161 & $\mathrm{~L}: 0.15$ \\
\hline Eye loin area $(\mathrm{cm})$ & 41.94 & 41.52 & 42.35 & 41.89 & 39.55 & 41.49 & \pm 4.579 & 0.99 \\
\hline 24-h post mortem $\mathrm{pH}$ & 5.65 & 5.66 & 5.66 & 5.56 & 5.62 & 5.63 & \pm 0.197 & 0.99 \\
\hline Marbling score & 2.25 & 1.95 & 1.75 & 1.55 & 2.06 & 1.91 & \pm 0.626 & Q:0.04 \\
\hline Abdominal fat (kg) & 1.17 & 1.07 & 1.09 & 1.02 & 1.09 & 1.09 & \pm 0.239 & $\mathrm{~L} ; 0.22$ \\
\hline Small intestine weight (kg) & 1.246 & 1.349 & 1.349 & 1.284 & 1.371 & 1.319 & \pm 0.132 & $\mathrm{~L}: 0.21$ \\
\hline Large intestine weight (kg) & 1.073 & 1.064 & 1.205 & 1.042 & 1.091 & 1.095 & \pm 0.143 & Q:0.25 \\
\hline Empty stomach weight (kg) & 0.383 & 0.377 & 0.430 & 0.412 & 0.423 & 0.407 & \pm 0.040 & $\mathrm{~L}: 0.01$ \\
\hline
\end{tabular}

$\mathrm{L}=$ linear effect, Empty stomach weight $=0.386232+0.0026344 \mathrm{X} ; \mathrm{Q}=$ Quadratic effect, Backfat thickness $=2.67681-0.088012 \mathrm{X}+0.00520290 \mathrm{X}^{2}$, Marbling score $=$ $2.29837-1.608804 \mathrm{X}+1.02554496 \mathrm{X}^{2}$. 
Table 7 - Economic analysis of using sticky coffee hull silage on growing-finishing pigs feeding

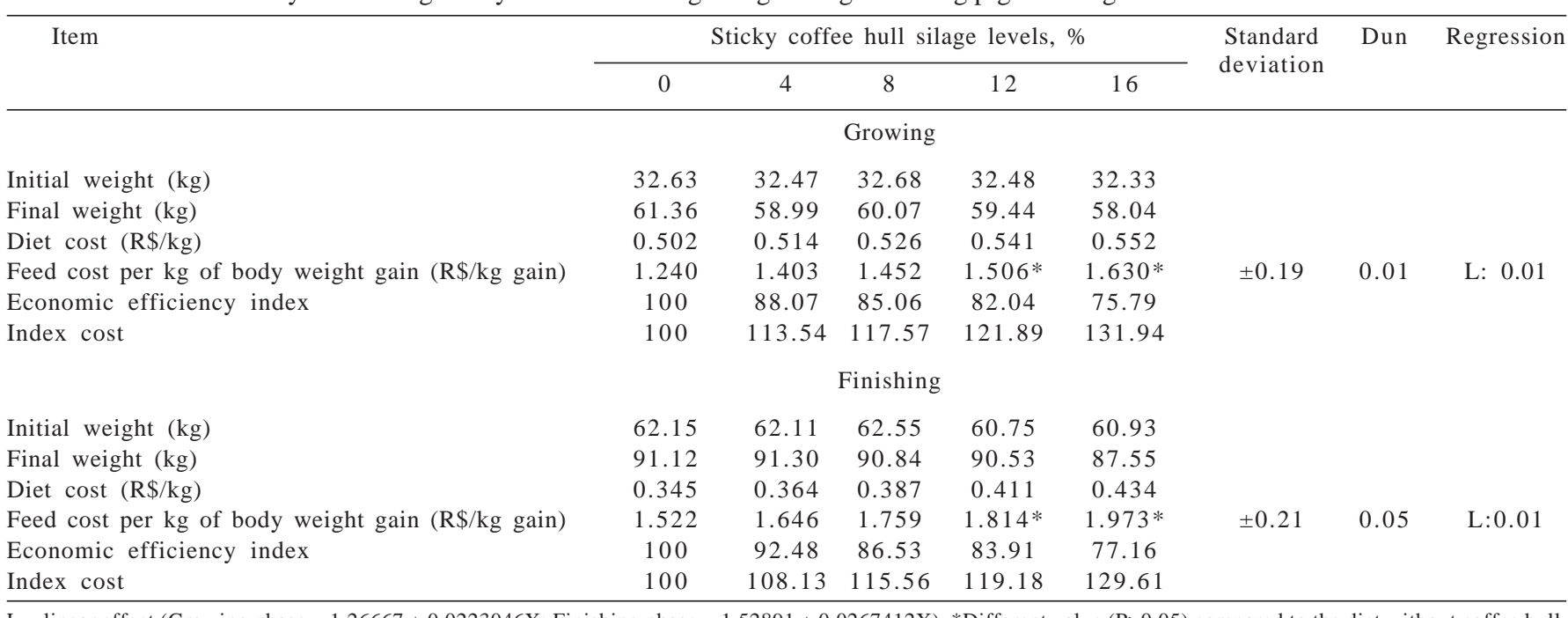

$\overline{\mathrm{L}}=$ linear effect (Growing phase $=1.26667+0.0223046 \mathrm{X}$; Finishing phase $=1.52891+0.0267412 \mathrm{X})$. ${ }^{*}$ Different value $(\mathrm{P}>0.05)$ compared to the diet without coffee hull.

response is probably related to the need to add oil, a high cost feedstuff, to the diets.

While the use of sticky coffee hull silage at levels of up to $16 \%$ and $8.4 \%$ is not harmul to the performance and to the carcass traits of pigs (30 to $90 \mathrm{~kg}$ ), respectively, its use increases the cost of the diet by 21 and 31\% in the growing phase and between 19 and 29\% in the finishing phase. However, if the relationship between the price of sticky coffee hull silage and the other feedstuffs (corn, soybean meal, soybean oil, and sticky coffee hull silage) improves, the use of this by-product in the composition of the diet may become economically feasible.

\section{Conclusions}

Ensiling does not improve the digestibility of the nutrients in sticky coffee hulls for growing-finishing pigs. The metabolizable energy values (as-fed-basis) of sticky coffee hull and sticky coffee hull silage are 2,050 and $1,357 \mathrm{kcal} / \mathrm{kg}$, respectively. Using up to $16 \%$ sticky coffee hull silage does not impair performance of growing and finishing pigs, while producing leaner carcasses. However, the economic feasibility of its use depends on the price relationship among the feedstuffs, in particular corn and soybean oil (or another energy source).

\section{Acknowledgements}

COCAMAR, for providing the sticky coffee hulls and CAPES and CNPq, for the scholarships and research grant.

\section{References}

ASSOCIAÇÃO BRASILEIRA DE CRIADORES DE SUÍNOS - ABCS Método brasileiro de classificação de carcaças. Estrela, 1973. 17p. (Publicação Técnica, 2).

BELLAVER, C.; FIALHO, E.T.; PROTAS, J.F.S. et al. Radícula de malte na alimentação de suínos em crescimento e terminação. Pesquisa Agropecuária Brasileira, v.20, n.8, p.969-74, 1985.

BRIDI, A.M.; SILVA, C.A. Métodos de avaliação da carcaça e da carne suína. Londrina: Midigraft, 2006. 97p.

CAI, Y.; ZIMMERMAN, D.R.; EWAN, R.C. Diurnal variation in concentrations of plasma urea nitrogen and amino acids in pigs given free access to feed or fed twice daily. Journal Nutrition, v.124, p.1088-1093, 1994.

CAMARA G.; SOUZA, R.C.M.; FREITAS U.M. et al. SPRING: Integrating remote sensing and GIS by object-oriented data modelling. Computers \& Graphics, v.20, n.3, p.395403, 1996

COMA, J.; CARRION, D.; ZIMMERMAN, D.R. Use of plasma urea nitrogen as a rapid response criterion to determine the lysine requirement of pigs. Journal of Animal Science, v.73, p.472-481, 1995.

COMPANHIA NACIONAL DE ABASTECIMENTO - CONAB. Avaliação da safra agrícola cafeeira 2007/2008 - Terceira estimativa - Agosto/2007. Disponível em: $<$ http:// www.conab.gov.br/conabweb/download/safra/3_levantamento_ 200708.pdf.> Acesso em: 24/10/2007.

FERREIRA, E.R.A.; FIALHO E.T.; TEIXEIRA A.S. et al. Avaliação da composição química e determinação de valores energéticos e equação de predição de alguns alimentos para suínos. Revista Brasileira de Zootecnia, v.26, n.3, p.514-523, 1997.

GOMES, J.D.F.; FUKUSHIMA, R.S.; PUTRINO, S.M. et al. Efeitos do incremento da fibra em detergente neutro na dieta de suínos sobre a morfologia dos órgãos digestivos e não digestivos. Brazilian Journal of Veterinary Research and Animal Science, v.43, n.2, p.202-209, 2006 .

GOMES, J.D.F.; PUTRINO, S.M.; GROSSKLAUS, C. et al. Efeitos do incremento de fibra dietética sobre a digestibilidade, desempenho e características de carcaça. I. Suínos em crescimento e terminação. Revista Semina, v.28, n.3, p.483-492, 2007. 
GOMES, M.F.M.; BARBOSA, H.P.; FIALHO, E.T. et al. Análise econômica da utilização de triguilho para suínos. Concórdia: EMBRAPA-CNPSA, 1991. p.1-2. (Comunicado Técnico, 179).

HORWITZ, W. Official methods of analysis of the Association of Official Analytical Chemists. 18.ed. Gaithersburg, Maryland: AOAC, 2005. p.17.

MARSH, W.H.; FINGERHUT, B.; MILLER, H. Automated and manual direct methods for determination of the determination of blood urea. Clinical Chemistry, v.11, n.6, p.624-627, 1965.

MATTERSON, L.D.; POTTER, L.M.; STUTZ, M.W. et al. The metabolizable energy of feed ingredients for chickens. Storrs: Connecticut University of Connecticut, Agricultural Experiment Station, 1965. v.7, p.11-14 (Research Report, 1).

MITARU, B.N.; REICHERT, R.D.; BLAIR, R. The binding of dietary protein by sorghum tannins in the digestive tract of pigs. The Journal of Nutrition, v.114, n.10, p.1787-1796, 1984.

MOREIRA, I.; MOURINHO, F.L.; CARVALHO, P.L.O. et al. Avaliação nutricional da casca de soja com ou sem complexo enzimático na alimentação de leitões na fase inicial. Revista Brasileira de Zootecnia, v.38, n.12, p.2408-2416, 2009.

NATIONAL RESEARCH COUNCIL - NRC. Nutrient requirements of swine. 10.ed. Washington. D.C.: 1998. 189p.

OLIVEIRA, S.L.; FIALHO, E.T.; MURGAS, L.D.S. et al. Utilização de casca de café melosa em rações de suínos em terminação. Ciência e Agrotecnologia, v.26, n.6, p.1330-1337, 2002.

OLIVEIRA, V.; FIALHO, E.T.; LIMA, J.A.F. et al. Substituição do milho por casca de café em rações isoenergéticas para suínos em crescimento e terminação. Ciência e Agrotecnologia, v.25, n.2, p.424-436, 2001.

PEKAS, J.C. Versatile swine laboratory apparatus for physiologic and metabolic studies. Journal Animal Science, v.27, n.5, p.1303-1309, 1968.

POND, W.G.; JUNG, H.G.; VAREL, V.H. Effect of dietary fiber on young adult genetically lean, obese, and contemporary pigs: body weight, carcass measurements, organ weights and digesta content. Journal of Animal Science, v.66, n.3, p.699-706, 1988.

POND, W.G.; VAREL, V.H. Comparative response of swine and rats to high-fiber or high-protein diets. Journal of Animal Science, v.67, p.716-723, 1989.

POVEDA PARRA, A.R.; MOREIRA, I.; FURLAN, A.C. et al. Utilização da casca de café na alimentação de suínos nas fases de crescimento e terminação. Revista Brasileira de Zootecnia, v.37, n.3, p.433-442, 2008.
QUADROS, A.R.B.; MOREIRA, I.; FURLAN, A.C. et al. Inclusão de diferentes níveis de casca de soja moída em dietas isoenergéticas para suínos em crescimento e terminação. Ciência Rural, v.38, n.2, p.463-469, 2008.

QUADROS, A.R.B.; MOREIRA, I.; PAIANO, D. et al. Avaliação nutricional da casca de soja integral ou moída, ensilada ou não, para suínos em fase de crescimento. Acta Scientiarum Animal Sciences, v.29, n.1, p.31-38, 2007.

RODRIGUES, P.H.M.; ALMEIDA, T.F.; MEYER, P.M. et al. Valor nutritivo da silagem de girassol inoculada com bactérias ácido-láticas. Revista Brasileira de Zootecnia, v.34, n.1, p.340-344, 2005.

ROSTAGNO, H.S.; ALBINO, L.F.T.; DONZELE, J.L. et al. Tabelas brasileiras para aves e suínos: composição de alimentos e exigências nutricionais. 2.ed. Viçosa, MG: UFV, 2005. 186p.

SAMPAIO, I.B.M. Estatística aplicada a experimentação animal. Belo Horizonte: Universidade Federal de Minas Gerais, 1998. p.221.

SANTOS, Z.A.S.; FREITAS, R.T.F.; FIALHO, E.T. et al. Valor nutricional de alimentos para suínos determinados na Universidade Federal de Lavras. Ciência e Agrotecnologia, v.29, n.1, p.232-237, 2005.

SILVA, D.J.; QUEIROZ, A.C. Análise de alimentos - métodos químicos e biológicos. 3.ed. Viçosa, MG: Universidade Federal de Viçosa, 2002. 235p.

STANOGIAS, G.; PEARCE, G.R. The digestion of fibre by pigs 1. The effects of amount and type of fibre on apparent digestibility, nitrogen balance and rate of passage. The British Journal of Nutrition, v.53, n.3, p.513-530, 1985a.

STANOGIAS, G.; PEARCE, G.R. The digestion of fibre by pigs 3. Effects of amount and type of fibre on physical characteristics of segments of the gastrointestinal tract. The British Journal of Nutrition, v.53, n.3, p.537-548, 1985b.

UNIVERSIDADE FEDERAL DE VIÇOSA - UFV. SAEGSistema de análises estatísticas e genéticas. Versão 7.1. Viçosa, MG, 1997. 150p. (Manual do usuário).

VILELA, F.G.; PEREZ, J.R.O.; TEIXEIRA, J.C. et al. Uso da casca de café melosa em diferentes níveis na alimentação de novilhos confinados. Ciência e Agrotecnologia, Lavras, v.25, n.1, p.198-205, 2001.

ZANOTTO, D.L.; BELLAVER, C.N. Métodos de determinação da granulometria de ingredientes para o uso em rações de suínos e aves. Concórdia: CNPSA-EMBRAPA, 1996. p.15. (Comunicado técnico, 215). 